\title{
STRATEGI PENGEMBANGAN EKONOMI DESA MENUJU DESA MANDIRI
}

\author{
Asbeni ${ }^{1)}$ \\ ${ }^{1}$ Politeknik Negeri Sambas, Jalan Raya Sejangkung Desa Sebayan Kabupaten Sambas
}

\begin{abstract}
ABSTRAK
Penelitian ini bertujuan untuk mendeskripsikan potensi ekonomi yang dapat mendukung pengembangan ekonomi di desa Sekura, dan mengkaji faktor-faktor yang menjadi kekuatan, kelemahan, peluang dan ancamannya terhadap pengembangan potensi desa, serta mengkaji bagaimana langkah pemerintah desa dan masyarakat dapat menentukan strategi pengembangan ekonomi menuju desa mandiri, yaitu desa yang dapat memenuhi kebutuhannya sendiri dan tidak tergantung dengan bantuan dari pemerintah.

Penelitian ini menggunakan metode analisis data kualitatif. Jenis data yang digunakan adalah data primer dan sekunder. Melalui kegiatan FGD Analisis data dilakukan dengan menggunakan analisis SWOT dan QSPM. Dari identifikasi, terdapat faktor-faktor internal yang menyebabkan Desa Sekura dapat mendorong pengembangan potensi ekonomi desa antara lain: Pertama, adanya keinginan untuk berkembang dari masyarakat itu sendiri. Kedua, Masyarakat memiliki kapasitas atau kemampuan untuk berwirausaha. Ketiga, kepala desa yang mampu mengorganisir masyarakat.

Penelitian menunjukkan bahwa potensi ekonomi di Desa Sekura meliputi: sektor perdagangan, kewirausahaan dan industri, sedangkan, faktor pendukung utama adalah keadaan sarana dan prasarana ekonomi masyarakat desa yang sudah memadai. Adapun strategi pengembangan berdasarkan SWOT adalah : a) Pendirian BUMDes dengan memanfaatkan SDM dan SDA yang dimiliki; b) Peningkatan kapasitas masyarakat dalam mengelola potensi yang dimiliki; c) meningkatkan kualitas masyarakat melalaui pelatihan tentang kewirausahaan; d) Peningkatan pemahaman masyarakat tentang potensi wirausaha. Tingkat kepentingan dari berbagai macam strategi yang didapatkan dari hasil SWOT, adalah sebagai berikut : 1)Pendirian BUMDes dengan memanfaatkan SDM dan SDA yang dimiliki; 2)Meningkatkan kualitas masyarakat melalaui pelatihan tentang kewirausahaan; 3)Peningkatan kapasitas masyarakat dalam mengelola potensi yang dimiliki; dan 4) Peningkatan pemahaman masyarakat tentang potensi wirausaha.
\end{abstract}

Kata Kunci: Desa Mandiri, Potensi Ekonomi, Strategi Pengembangan.

\section{Pendahuluan}

Desa adalah suatu wilayah yang ditempati sejumlah penduduk sebagai kesatuan masyarakat yang di dalamnya merupakan kesatuan hukum yang memiliki organisasi pemerintahan terendah langsung di bawah camat, dan berhak menyelenggarakan rumah tangganya sendiri (otonomi) dalam ikatan negara kesatuan Republik Indonesia. Menurut Adisasmita (2006: 1) Sekitar 65\% jumlah penduduk hidup di daerah pedesaan, sisanya sekitar 35\% jumlah penduduk menetap di daerah perkotaan.

Secara khusus perlu diberikan perhatian kepada masyarakat pedesaan khususnya masalah-masalah yang menghambat proses pergerakan dan perubahan masyarakat pedesaan sehingga mereka dapat ikut serta dalam pembangunan nasional. Timbulnya perubahan-perubahan dengan variasivariasi pendekatan terhadap pembangunan pedesaan, sebagai usaha untuk menyentuh dan 
memperbaiki taraf hidup kelompok masyarakat miskin disebabkan oleh kompleksnya dan sukarnya mengatasi keterbelakangan pedesaan.

Kesulitan tersebut tidak hanya bersumber dari faktor-faktor yang sifatnya ekonomis mikro, seperti kekurangan modal, teknologi yang kurang memadai, sarana dan prasarana yang minim, tetapi juga hambatan-hambatan yang bersumber dari dimensi struktur masyarakat pedesaan, seperti susunan kekuasaan dan pola-pola kelembagaan tradisional. Untuk meningkatkan pembangunan di desa berbagai program pembangunan telah dilakukan, perencanaan dan implementasinya ternyata masih belum memberikan hasil yang optimal. Faktor-faktor yang dapat mempengaruhi tingkat dan arah perkembangan desa adalah faktor lokasi, atau letak desa terhadap pusat-pusat fasilitas dan jalan perhubungan (lancar atau tidak lancar).

Pada hakekatnya pembangunan desa dilakukan oleh masyarakat bersama-sama pemerintah terutama dalam memberikan bimbingan, pengarahan, bantuan pembinaan, dan pengawasan agar dapat ditingkatkan kemampuan masyarakat dalam usaha menaikkan taraf hidup dan kesejahteraannya. Kewajiban pemerintah adalah menyediakan prasarana-prasarana, sedangkan selebihnya disandarkan kepada kemampuan masyarakat itu sendiri.

Untuk mendukung upaya pencapaian sasaran pembangunan desa dan kawasan perdesaan, yakni mengentaskan 5000 Desa Tertinggal dan meningkatkan sedikitnya 2000 Desa Mandiri sebagaimana tertuang dalam Rencana Pembangunan Jangka Menengah Nasional 2015 - 2019, diperlukan kejelasan status kemajuan dan kemandirian desa di seluruh Indonesia. Seperti yang sudah dinyatakan secara normatif dalam UndangUndang Nomor 6 Tahun 2014 Tentang Desa (selanjutnya disebut Undang-Undang Desa), bahwa tujuan pembangunan desa adalah untuk meningkatkan kesejahteraan masyarakat desa, kualitas hidup manusia dan menanggulangi kemiskinan.

Dengan demikian, tindakan kebijakan pembangunan dan pemberdayaan masyarakat desa harus diabdikan pada pencapaian tujuan pembangunan desa itu. Berdasarkan Indeks
Desa Membangun (IDM) dalam Peraturan Menteri Desa No 2 Tahun 2016, status kemajuan dan kemandirian desa dijelaskan dengan klasifikasi yang diharapkan dapat memfasilitasi pemahaman tentang situasi dan kondisi desa saat ini, serta bagaimana langkah kebijakan yang harus dikembangkan untuk mendukung peningkatan kehidupan desa menjadi lebih maju dan mandiri.

Oleh karena itu, sangat diperlukan suatu penelitian tentang strategi pengembangan ekonomi kerakyatan menuju Desa Mandiri di Desa Sekura Kecamatan Teluk Keramat kabupaten Sambas. Adapun tujuan dari penelitian ini adalah:

a. Mengidentifikasi potensi-potensi unggulan untuk mendukung pengembangan ekonomi kerakyatan menuju desa mandiri yang ada di desa Sekura.

b. Mengkaji faktor kekuatan, kelemahan, peluang dan ancamannya terhadap pengembangan ekonomi kerakyatan menuju desa mandiri yang ada di desa Sekura.

c. Merumuskan strategi pengembangan ekonomi kerakyatan menuju desa mandiri yang ada di desa Sekura.

\section{Metodologi}

Untuk analisis data pada kajian ini dibutuhkan data yang terdiri dari dua sumber data, yaitu: Data primer, merupakan data utama yang diperoleh langsung dari lapangan. Untuk mendapatkan data tersebut digunakan kuesioner, dan pengumpulan data dilakukan melalui:

a. Wawancara langsung; Wawancara langsung dalam hal ini dilakukan melalui Focus Group Discussion (FGD) dengan semua perangkat desa.

b. Observasi; Teknik ini digunakan untuk melakukan pencatatan secara teliti dan sistematis terhadap obyek kajian yang langsung diamati di lapangan guna melengkapi teknik wawancara.

Data sekunder, merupakan data pendukung yang diperoleh melalui penelusuran studi kepustakaan berupa literatur, dokumen, jurnal dan laporan penelitian, majalah dan karya ilmiah yang berkaitan dengan masalah 
penelitian dan juga melalui media internet. Analisis adalah proses menyusun data agar dapat ditafsirkan. Analisis data yang digunakan dalam penelitian ini melalui:

\section{a. Analisis Focus Group Discussion (FGD)}

Focus Group Discussion (FGD) merupakan diskusi kelompok yang dilakukan secara sistematis dan terarah atas suatu isu atau masalah tertentu. FGD dirancang sedemikian rupa untuk mendapatkan informasi tertentu. FGD merupakan salah satu bentuk riset dalam penelitian sosial dan pelaksanaannya dilakukan dengan prosedur tertentu. Penyelenggara menentukan tujuan riset dan merumuskan tujuan tersebut ke dalam tahapan-tahapan FGD (Lingkaran Survei Indonesia, 2006).

Adapun ciri-ciri penting dari FGD adalah terfokus dan terarah. FGD dikatakan sebuah diskusi yang terfokus dan terarah karena: 1) Topik ataupun materi yang akan didiskusikan telah ditentukan oleh penyelenggara, dan 2) Peserta FGD sudah ditentukan ataupun diseleksi sedemikian rupa sesuai dengan tujuan dan target informasi yang ingin didapat dari sebuah FGD.

FGD memiliki beberapa karakteristik, yaitu: 1) berupa format diskusi, 2) peserta FGD berjumlah antara $6-12$ orang, 3) panjang/lama diskusi yang dilakukan antara 1,5 - 2 jam persesi, 4) peserta diskusi sudah diseleksi atau ditentukan berdasarkan karakteristik atau ciri yang sama oleh penyelenggara sesuai dengan tujuan riset, 5) bentuk data berupa percakapan (termasuk intonasi atau mimik muka) dan gerak tubuh dan bahasa non verbal, 6) pengambilan data dapat dilakukan melalui rekaman diskusi baik audio maupun video serta transkrip hasil diskusi, 7) moderator menggunakan petunjuk pelaksanaan diskusi yang dilengkapi dengan topik-topik yang akan didiskusikan termasuk alokasi waktu dari masing-masing topik, 8) bentuk serta format laporan berupa deskripsi dan narasi dengan pengutipan pilihan komentar atau pendapat. Analisis ditujukan pada aspek yang banyak dibicarakan seperti argumentasi yang banyak muncul, dan sudut pandang yang banyak keluar dari peserta (Lingkaran Survei Indonesia, 2006).

FGD merupakan salah satu bentuk penelitian sosial. FGD dilakukan untuk mengetahui pendapat, persepsi dan pengalaman individu. FGD tidak memiliki pretensi untuk melakukan generalisasi atau menggambarkan pendapat atau persepsi masyarakat secara akurat. Tujuan dari FGD adalah untuk pendalaman (insight) terhadap suatu isu, masalah atau topik tertentu. Peserta FGD yang diseleksi adalah homogen, yaitu peserta yang dipilih berdasarkan karakteristik dan latar belakang yang sama. Pengambilan data FGD bersifat sosial, artinya peserta FGD saling berinteraksi dalam menyampaikan, mendengarkan maupun dalam mendebat pendapat orang lain. Dalam penelitian ini dilakukan FGD terhadap semua perangkat desa yang terkait dengan manajemen resiko pengelolaan keuangan desa di Desa Sekura Kecamatan Teluk Keramat. Peserta FGD melakukan diskusi mengenai beberapa topik untuk mendapatkan suatu kesimpulan yang dapat digunakan untuk mengetahui pandangan terhadap resiko dalam pengelolaan keuangan. Wawancara dalam FGD dilakukan secara langsung dan dibantu dengan memberikan pertanyaan dalam bentuk kuesioner.

Data yang telah diperoleh dalam kajian ini, baik primer maupun sekunder diolah secara deskriptif dalam bentuk frekuensi, persentase, rataan skor, dan tabulasi silang. Kajian dilakukan dengan analisa SWOT yang bertujuan untuk mengetahui pengaruh dan frekuansi terjadinya risiko dalam pengelolaan keuangan desa. Alat analisis yang sederhana dan cukup baik, efektif dan efisien dalam memisahkan masalah-masalah utama yang dihadapi baik berupa faktor internal dan eksternal. Ada beberapa tahapan dalam penyusunan dalam SWOT, seperti:

a. Lingkungan eksternal adalah segala kekuatan yang ada di luar organisasi, pengaruh organisasi tidak terlihat sama sekali. Lingkungan eksternal sangat mempengaruhi kinerja organisasi. Lingkungan eksternal tersebut terdiri atas lingkungan umum.

b. Lingkungan internal suatu organisasi adalah hasil analisis dari nilai atau identifikasi segala faktor yang memengaruhi kinerja organisasi. Kumpulan sumber daya, kapasitas dan kompetensi yang dimiliki oleh organisasi, sehingga mampu memanfaatkan peluang 
dengan cara efektif dan secara bersama mampu mengatasi ancaman.

Setelah melakukan analisis faktor internal dan eksternal organisasi, maka langkah selanjutnya adalah menyusun matriks Internal Factor Evaluation (IFE) dan External Factor Evaluation (EFE) yang kemudian diberikan rating. Pe-nentuan rating oleh pakar atau manajemen di organisasi dilakukan terhadap peubah-peubah hasil analisis dan memberikan peringkat dengan skala yang di-tetapkan, misalnya 1, 2, 3, dan 4.

Matriks IFE dan EFE selanjutnya diberi bobot dan dikalikan dengan peringkat pada setiap faktor untuk menghasilkan skor. Dari skor yang diperoleh kemudian dapat diketahui posisi organisasi pada matriks Internal dan Eksternal (IE). Hal ini penting dilakukan, agar strategi yang diterapkan mampu mengembangkan usaha dengan baik. Pemberian bobot dan rating pada matriks IFE dan EFE didasari atas kuesioner yang diberikan kepada semua yang ada di organisasi atau perangkat desa

Langkah selanjutnya melakukan analisis strategi dengan analisis SWOT, yaitu analisis kekuatan-kelemahan (StrenghtsWeaknesses) dan peluang-ancaman (Opportunities-Threats). Matriks SWOT akan menghasilkan empat tipe strategi yaitu: (a) strategi Strenghts-Opportunities, (b) strategi Strenghts-Threats, (c) strategi WeaknessesOpportunities dan (d) strategi WeaknessesThreats. Model matriks untuk menganalisis SWOT akan digambarkan secara jelas bagaimana peluang dan ancaman eksternal dalam kebijakan pengembangan organisasi dapat disesuaikan dengan kekuatan dan kelemahan yang dimiliki internal organisasi, seperti berikut ini:

a. Strategi SO; Strategi ini dilakukan untuk memanfaatkan seluruh kekuatan untuk merebut dan memanfaatkan peluang dengan sebesar-besarnya.

b. Strategi ST; Strategi ini dilakukan untuk menggunakan kekuatan yang dimiliki untuk mengatasi ancaman yang ada.

c. Strategi WO; Strategi ini dilaksanakan berdasarkan pemanfaatan peluang yang ada dengan cara meminimalkan kelemahan yang ada. d. Strategi WT; Strategi kegiatan yang bersifat defensif dan berusaha untuk meminimalkan kelemahan yang ada serta untuk menghindari ancaman.

Setelah semua data terangkum dalam matriks SWOT, selanjutnya akan dilanjutkan pada tahap terakhir yaitu penggunaan Quantitative Strategic PlanningMatrix (QSPM). QSPM digunakan untuk merumuskan strategi mana yang terbaik sebagai strategi alternatif, yang obyektif, berdasarkan faktorfaktor sukses internal dan eksternal yang telah dikenali sebelumnya (David, 2006). Seperti dalam tabel berikut:

Tabel Matriks QSP

\begin{tabular}{|l|l|l|l|l|l|}
\hline \multirow{2}{*}{$\begin{array}{l}\text { Faktor- } \\
\text { faktor }\end{array}$} & \multirow{2}{*}{ kobot } & \multicolumn{3}{|c|}{ Alternatif strategi } \\
\cline { 3 - 6 } & & \multicolumn{2}{|c|}{ Strategi 1 } & \multicolumn{2}{c|}{ Strategi 2 } \\
\cline { 3 - 5 } & & AS & TAS & AS & TAS \\
\hline $\begin{array}{l}\text { Faktor } \\
\text { Internal }\end{array}$ & & & & & \\
\hline $\begin{array}{l}\text { Faktor } \\
\text { Eksternal }\end{array}$ & & & & & \\
\hline \multicolumn{2}{|c|}{ Jumlah total nilai daya tarik } & & & \\
\hline
\end{tabular}

Keterangan: $\quad \mathrm{AS}=$ nilai daya tarik, $\mathrm{TAS}=$ total nilai daya Tarik, Nilai daya tarik: $1=$ tidak menarik/mempengaruhi, $2=$ agak mempengaruhi, 3 = cukup mempengaruhi, dan 4 = sangat mempengaruhi

\section{Hasil dan Pembahasan}

Potensi-potensi untuk mendukung pengembangan ekonomi kerakyatan menuju desa mandiri yang diunggulkan di desa Sekura seperti berikut ini :

a. Pertanian dan Perkebunan

Sebagian besar masyarakat Desa Sekura (khususnya wilayah Dusun Penagaman, Sekura Barat, Mensungai, dan Kelumpang) berprofesi sebagai petani dan pekebun. Pada sektor pertanian, masyarakat pada umumnya menanam padi. Pada sektor perkebunan, masyarakat banyak yang berkebun karet. Di wilayah dusun Penagaman dan Sekura Barat, masyarakat pada umumnya berkebun salak. Sebagian kecil warga juga berkebun jeruk dan lada.

b. Perdagangan

Perdagangan merupakan salah satu potensi unggulan masyarakat yang ada di Desa Sekura, terutama di wilayah dusun Sekura Utara 
dan Sekura Selatan, karena wilayah tersebut merupakan daerah pasar.

c. Industri

Pada sektor industri, masyarakat mempunyai industri kecil sampai menengah, seperti industri tempe, makanan kecil, industri mebel, dan sebagian industri keterampilan tangan.

d. Wirausaha

Wirausaha yang dimaksud adalah usahausaha yang dijalankan oleh masyarakat seperti rumah makan, café, dan warung kopi.

Adapun kriteria yang dijadikan tolok ukur dalam menentukan skala prioritas potensi yang akan dikembangkan berdasarkan:

a. Hasil atau pendapatan yang diperoleh.

b. Peningkatan kesejahteraan pelaku.

c. Tingkat perkembangan (jumlah pelaku, intensitas) potensi dari tahun ke tahun.

d. Biofisik wilayah atau letak geografis wilayah.

e. Ketersedian pasar atau konsumen

Berdasarkan data hasil penelilitian di lapangan diketahui bahwa dari 4 jenis potensi yang dimiliki oleh desa Sekura kecamatan Teluk Keramat, responden memilih wirausaha menjadi potensi yang paling utama untuk dikembangkan yaitu sebesar $60 \%$, perdagangan $20 \%$, dan pertanian/perkebunan $20 \%$.

3.1. Mengkaji faktor kekuatan, kelemahan, peluang dan ancamannya terhadap pengembangan ekonomi kerakyatan menuju desa mandiri yang ada di desa Sekura.

a. Faktor Internal

Analisis lingkungan internal bertujuan untuk mengidentifikasi dan menjelaskan faktorfaktor yang menjadi kekuatan dan kelemahan dalam pengembangan ekonomi kerakyatan menuju desa mandiri yang ada di desa Sekura. Adapun faktor yang menjadi kekuatan dan kelemahan seperti berikut ini:

1. Faktor kekuatan; SDM tersedia, tingkat pendidikan sudah tinggi, kinerja perangkat desa sudah memadai

2. Faktor kelemahan; belum memiliki infrastruktur perekonomian, kurangnya akses informasi tentang usaha, tingkat perekonomian masyarakat yang masih rendah, sarana dan prasarana transportasi masih kurang memadai, b. Faktor Eksternal

Analisis lingkungan eksternal bertujuan untuk mengidentifikasi dan menjelaskan faktorfaktor yang menjadi peluang dan ancaman/tantangan dalam pengembangan ekonomi kerakyatan menuju desa mandiri yang ada di desa Sekura.

1. Faktor peluang; letak georgrafis yang sangat strategis, desa belum memiliki BUMDES, akses sungai yang belum dimanfaatkan secara maksimal, akses lembaga keuangan sudah tersedia, kemajuan teknologi dan informasi.

2. Faktor ancaman/tantangan; rendahnya minat masyarakat dalam pengembangan usaha, situasi politik dan keamanan yang tidak menentu

3.2. Analisis Matriks IFE (Internal Faktor Evaluation Matrix) dan Matriks EFE (External Faktor Evaluation Matrix)

a. Matriks IFE (Internal Faktor Evaluation Matrix)

\begin{tabular}{|c|c|c|c|c|}
\hline \multicolumn{2}{|c|}{ Kekuatan } & $\begin{array}{c}\text { bobo } \\
\mathbf{t}\end{array}$ & $\begin{array}{c}\text { ratin } \\
\mathrm{g}\end{array}$ & $\begin{array}{l}\text { nilai } \\
\text { skor }\end{array}$ \\
\hline a. & $\begin{array}{l}\text { Tingkat } \\
\text { Pendidikan } \\
\text { masyarakat } \\
\text { sudah tinggi }\end{array}$ & 0,083 & 3,250 & $\begin{array}{c}0,27 \\
1\end{array}$ \\
\hline b. & SDM tersedia & 0,110 & 3,500 & $\begin{array}{c}0,38 \\
5 \\
\end{array}$ \\
\hline c. & $\begin{array}{l}\text { kinerja } \\
\text { perangkat desa } \\
\text { sudah } \\
\text { memadai }\end{array}$ & 0,104 & 3,000 & $\begin{array}{c}0,31 \\
3\end{array}$ \\
\hline \multicolumn{5}{|c|}{ Kelemahan } \\
\hline d. & $\begin{array}{l}\text { belum } \\
\text { memiliki } \\
\text { infrastruktur } \\
\text { perekonomian }\end{array}$ & 0,179 & 1,750 & $\begin{array}{c}0,31 \\
3 \\
\end{array}$ \\
\hline e. & $\begin{array}{l}\text { kurangnya } \\
\text { akses } \\
\text { informasi } \\
\text { tentang usaha }\end{array}$ & 0,179 & 1,750 & $\begin{array}{c}0,31 \\
3 \\
\end{array}$ \\
\hline f. & $\begin{array}{l}\text { tingkat } \\
\text { perekonomian } \\
\text { masyarakat } \\
\text { yang masih } \\
\text { rendah }\end{array}$ & 0,173 & 1,250 & $\begin{array}{c}0,21 \\
6\end{array}$ \\
\hline
\end{tabular}




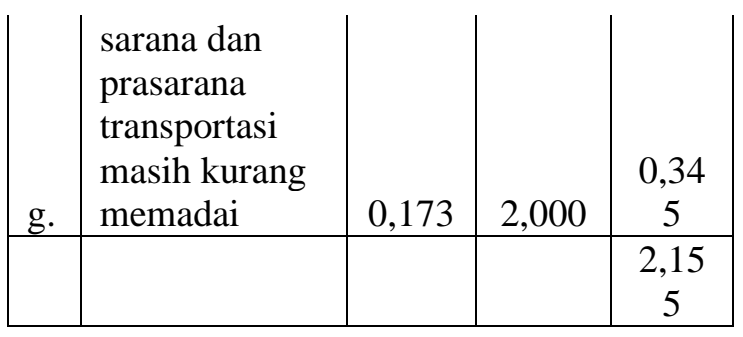

b. Matriks EFE (Eksternal Faktor Evaluation Matrix)

\begin{tabular}{|c|c|c|c|c|}
\hline \multicolumn{2}{|c|}{ Peluang } & $\begin{array}{c}\text { bobo } \\
t\end{array}$ & $\begin{array}{c}\text { ratin } \\
\mathbf{g}\end{array}$ & $\begin{array}{l}\text { nilai } \\
\text { skor }\end{array}$ \\
\hline a. & $\begin{array}{l}\text { letak } \\
\text { georgrafis } \\
\text { yang sangat } \\
\text { strategis }\end{array}$ & 0,134 & 3,750 & $\begin{array}{c}0,50 \\
2\end{array}$ \\
\hline b. & $\begin{array}{l}\text { kemajuan } \\
\text { teknologi dan } \\
\text { informasi }\end{array}$ & 0,116 & 3,500 & $\begin{array}{c}0,40 \\
6\end{array}$ \\
\hline c. & $\begin{array}{l}\text { desa belum } \\
\text { memiliki } \\
\text { BUMDes }\end{array}$ & 0,116 & 3,000 & $\begin{array}{c}0,34 \\
8\end{array}$ \\
\hline d. & $\begin{array}{l}\text { akses sungai } \\
\text { yang belum } \\
\text { dimanfaatkan } \\
\text { secara } \\
\text { maksimal }\end{array}$ & 0,125 & 3,000 & $\begin{array}{c}0,37 \\
5\end{array}$ \\
\hline \multicolumn{5}{|c|}{ ancaman/tantangan } \\
\hline e. & $\begin{array}{l}\text { rendahnya } \\
\text { minat } \\
\text { masyarakat } \\
\text { dalam } \\
\text { pengembanga } \\
\text { n usaha }\end{array}$ & 0,196 & 1,250 & $\begin{array}{c}0,24 \\
6\end{array}$ \\
\hline f. & $\begin{array}{l}\text { situasi politik } \\
\text { dan keamanan } \\
\text { yang tidak } \\
\text { menentu }\end{array}$ & 0,113 & 2,000 & $\begin{array}{c}0,22 \\
6\end{array}$ \\
\hline g. & $\begin{array}{l}\text { keterbatasan } \\
\text { modal }\end{array}$ & 0,199 & 1,250 & $\begin{array}{c}0,24 \\
9\end{array}$ \\
\hline & & & & $\begin{array}{c}2,35 \\
3\end{array}$ \\
\hline
\end{tabular}

3.3. Merumuskan strategi pengembangan ekonomi kerakyatan menuju desa mandiri yang ada di desa Sekura.

a. Analisis SWOT

Berdasarkan hasil evaluasi matriks IFE dan EFE, disusunlah matriks SWOT yang menghasilkan empat tipe strategi yang dapat dilakukan, yaitu strategi S-O, W-O, S-T, dan W-T. Hasil analisis SWOT dan Alternatif strategi terapan yang muncul dari matriks SWOT seperti berikut:

1. Pendirian BUMDes dengan memanfaatkan SDM dan SDA yang dimiliki.

2. Peningkatan kapasitas masyarakat dalam mengelola potensi yang dimiliki.

3. Meningkatkan kualitas masyarakat melalaui pelatihan tentang kewirausahaan.

4. Peningkatan pemahaman masyarakat tentang potensi wirausaha

b. Analisis QSPM (Quantitative Strategic Planning Matrix)

Tabel Hasil dari Penlinalian QSPM

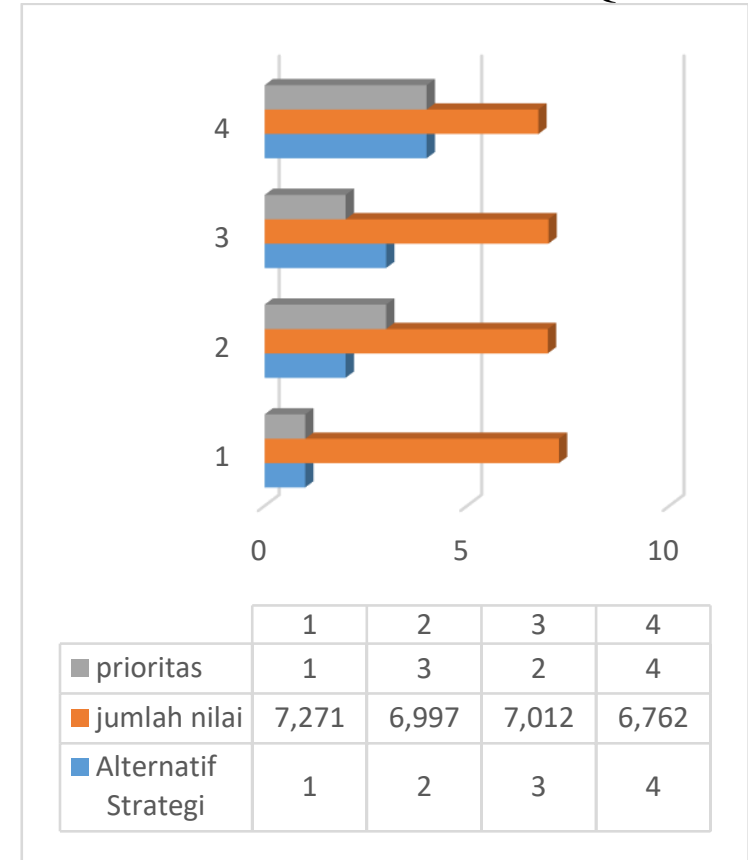

Berdasarkan hasil dari penilaian QSPM diketahui bahwa yang menjadi prioritas strategi pengembangan ekonomi menuju desa mandiri di desa Sekura dari urutan pertama sampai ke empat adalah:

1. Pendirian BUMDes dengan memanfaatkan SDM dan SDA yang dimiliki dengan nilai 7,271 . 
2. Meningkatkan kualitas masyarakat melalaui pelatihan tentang kewirausahaan dengan nilai 7,012 .

3. Peningkatan kapasitas masyarakat dalam mengelola potensi yang dimiliki dengan nilai $9,997$.

4. Peningkatan pemahaman masyarakat tentang potensi wirausaha dengan nilai 6,762 .

\section{Simpulan}

Berdasarkan hasil penelitian di lapangan dapat di ambil simpulan sebagai berikut:

a. Hasil identifikasi potensi unggulan yang menjadi prioritas adalah wirausaha.

b. Urutan prioritas dari strategi pengembangan ekonomi kerakyatan menuju desa mandiri yang ada di desa Sekura adalah Pendirian BUMDes dengan memanfaatkan SDM dan SDA yang dimiliki.

\section{Daftar Pustaka}

Adisasmita, Rahardjo. 2006. Pembangunan

Pedesaan Dan Perkotaan. Graha Ilmu, Yogyakarta

David, F. R. 2004. Strategic Management. $6^{\text {th }}$ Ed. New Jersey, USA: Pretice Hall Engelewood Cliffs.

David, F.R. 2006. Manajemen Strategi (Terjemahan). PT. Prenhallindo, Jakarta.

Husaeni, UA. 2017. Potensi Ekonomi Desa Mandiri (Studi di Desa Sukamanah Karangtengah Kabupaten Cianjur). Jurnal Of Empowerment, VOL. 1, No. 1, Juni 2017, h.1-12

Rangkuti, F. 2010. Analisis SWOT Teknik Membedah Kasus Bisnis : Reorientasi Konsep Perencanaan Strategi untuk Menghadapi Abad 21. PT. Gramedia Pustaka Utama, Jakarta.

Soleh, A. 2017. Strategi Pengembangan Potensi Desa. Jurnal Sungkai Vol.5 No.1, Edisi Februari 2017 Hal : 32-52 